\title{
STUDI TENTANG PEMANFAATAN LAHAN DENGAN POLA AGROFORESTRY PADA KEBUN BELIMBING DI DESA MANUNGGAL JAYA KECAMATAN TENGGARONG SEBRANG
}

\author{
Rahmat Andriansyah, Abdul Kholik Hidayah, Mohammad Taufan Tirkaamiana ${ }^{1}$ \\ ${ }^{1}$ Prodi Kehutanan, Fakultas Pertanian, Universitas 17 Agustus 1945 Samarinda 75124, \\ Indonesia. Jl. Ir. H. Juanda No.80 Samarinda 75124, Kalimantan Timur Indonesia. \\ E-Mail: rahmat.andriansyah@gmail.com
}

\begin{abstract}
ABSTRAK
Studi Tentang Pemanfaatan Lahan Dengan Pola Agroforestry Pada Kebun Belimbing Di Desa Manunggal Jaya, Kecamatan Tenggarong Seberang Kabupaten Kutai Kartanegara. Manfaat yang dapat diperoleh dari pengelolaan kebun yang berbasis agroforestry adalah produksi hasil tanaman berjangka panjang bagi petani secara ekonomi dan menjaga tanah tetap subur serta produktif.

Tujuan Penelitian adalah bertujuan untuk mendeskripsikan pola agroforestry dari aspek ekologi dan ekonomi pada kebun belimbing di Desa Manunggal Jaya, Kecamatan Tenggarong Seberang, Kabupaten Kutai Kartanegara.

Penelitian ini dilaksanakan dari bulan Juni sampai Juli 2019 dan bertujuan untuk mengetahui pola agroforestry dalam pemanfaatan lahan yang diterapkan oleh pemilik lahan, baik itu dari aspek finansial maupun aspek ekologi.

Metode pada penelitian ini menggunakan metode ekplorasi melalui observasi langsung dilapangan dengan menggunakan wawancara sebagai alat pengumpulan data. Data dan informasi dikumpulkan melalui pembuatan kuisioner wawancara, studi dokumentasi, pengamatan dilapangan, kemudian diklasifikasi segala jenis biaya yang diperlukan dalam usahatani ini sehingga dapat diketahui layak atau tidaknya usaha ini dijalankan.

Hasil penelitian ini menunjukan bahwasannya pola agroforestry yang diterapkan adalah dengan sistem agroforestry kebun campuran dengan pola tanam acak dan pola tanam teratur, untuk tanaman belimbing merupakan tanaman yang paling sering dijumpai bersama juga tanaman jambu air dan jambu kristal. Sedangkan hasil dari analisis finansial menunjukan Net Present Value > 0 yaitu Rp. 586.153.801 pada suku bunga 20\%, Net Benefit Cos Ratio > 1 yaitu 5,35 pada suku bunga 10\%, dan Internal Rate Of Return 19,4\% pada tahun ke 7 .
\end{abstract}

Kata kunci : Agroforestry, Kebun belimbing, Pemanfaatan lahan.

\begin{abstract}
The study is about Land Use Agroforestry Pattern at Star fruit Orchard at Desa Manunggal Jaya Kecamatan Tenggarong Seberang Kabupaten Kutai Kartanegara. The benefits that can be obtained from agroforestry-based garden management are the production of long-term crops for farmers economically and to keep the soil fertile and productive.

The objective of the study was to describe the agroforestry pattern from ecological and economic aspects in the star fruit garden in Manunggal Jaya Village, Tenggarong Seberang District, Kutai Kartanegara Regency.

The study had conducted since June to July 2019 with the purpose is studying agroforestry pattern in land use that is applied by the landlord, either it is seen from aspect financial and ecological aspect.

The study exploration method by observing directly on the spot, using interview technique as a tool to collect data. All data and information was collected by conducting questionnaire for interview, documentary study, observation, then all the expenses that used for the agriculture activity was classified. Therefore the study will show whether the activity is worth to do or not.

The result of the study shows that the agroforestry pattern which used in this activity was agroforestry system with multiple cropping by using random cropping pattern and regular crop pattern. For star fruit, it is the most familiar crop to find, along with rose apple and guava. And for the result of financial analysis shows
\end{abstract}


that Net Present Value > 0 that is 586.153.801 with 20\% of interest rate, Net Benefit Cost Ratio > 1 that is 5,35 with $20 \%$ of interest rate and Internal Rate of Return 19,4\% in the $7^{\text {th }}$ year.

Key words : Agroforestry, Land use, star fruit gardens.

\section{PENDAHULUAN}

Hutan sebagai karunia dan amanah Tuhan Yang Maha Esa yang dianugerahkan kepada bangsa Indonesia, merupakan kekayaan yang dikuasai oleh Negara, memberikan manfaat serbaguna bagi umat manusia, karenanya wajib disyukuri, diurus, dan dimanfaatkan secara optimal, serta dijaga kelestariannya untuk sebesar-besarnya kemakmuran rakyat, bagi generasi sekarang maupun generasi mendatang (UU No 41 tahun 1999).

Dewasa ini konversi hutan menjadi lahan pertanian disadari menimbulkan banyak masalah seperti penurunan kesuburan tanah, erosi, kepunahan flora dan fauna, banjir, kekeringan dan perubahan lingkungan. Oleh karena itu perlu adanya strategi jangka panjang untuk mendukung pengelolaan hutan secara baik dan berkelanjutan (Utami, 2003).

Pengelolaan hutan yang baik tentunya berdampak terhadap kondisi ekonomi masyarakat sekitar hutan. Salah satu bentuk pengelolaan hutan di Indonesia adalah pola agroforestry. Agroforestry adalah salah satu sistem pengelolaan lahan yang berfungsi produktif dan protektif (mempertahankan keanekaragaman hayati, ekosistem sehat, konservasi air dan tanah, lubuk C daratan), sehingga seringkali dipakai sebagai salah satu contoh sistem pengelolaan lahan yang berkelanjutan (Utami dkk., 2003).

Paembonan (2012), mengatakan bahwa agroforestry mempunyai manfaat secara langsung dan tidak langsung. Manfaat langsung dari keberadaan hutan diantaranya adalah kayu, hasil hutan bukan kayu dan satwa, sedangkan manfaat tidak langsungnya adalah berupa jasa lingkungan, baik sebagai pengatur tata air, fungsi estetika, maupun sebagai penyedia oksigen dan penyerap karbon.

Alih-guna lahan menjadi lahan pertanian telah banyak menimbulkan banyak masalah seperti penurunan kesuburan tanah, erosi maupun perubahan lingkungan global. Agroforestry merupakan salah satu sistem pengelolaan lahan yang dapat ditawarkan untuk mengatasi masalah yang timbul akibat adanya alih-guna lahan dan sekaligus juga untuk mengatasi masalah pangan (Hairiah, dkk., 2003).

Mahendra (2009) menyatakan bahwa sistem Agroforestry merupakan sistem bercocok tanam multikultur, yang mengkombinasikan tanaman kehutanan dan tanaman pertanian, hewan atau tanaman lainnya dalam suatu lahan secara bersamaan maupun periodik. Salah satu sistem agroforestry yang dapat meningkatkan pendapatan petani yang dikenal secara luas dan dipraktekkan masyarakat adalah kebun campuran, yaitu kebun yang ditanami dengan tanaman kehutanan dan tanaman pertanian secara bersamaan dalam satu lahan. Manfaat dari sistem agroforestry bukan hanya memberikan keuntungan sosial ekonomi bagi petani, tetapi juga memberikan manfaat tersendiri bagi lingkungan hidup.

Manfaat yang dapat diperoleh dari pengelolaan kebun yang berbasis agroforestry dari segi lingkungan adalah mengurangi aliran permukaan, pencucian zat hara tanah dan laju erosi, meningkatkan jumlah serasah yang dapat terdekomposisi menjadi bahan organik tanah, memperbaiki struktur tanah serta meningkatkan keanekaragaman hayati, sedangkan manfaat sosial ekonomi dari sistem agroforestry adalah meningkatkan produktivitas karena hasil panen yang 
beragam sehingga mampu memantapkan pendapatan petani. Kelestarian produktivitas tanaman yang berumur panjang, dapat menjadi sumber tabungan jangka panjang bagi petani.

Berdasarkan uraian diatas, maka perlu dilakukan penelitian untuk mendeskripsikan sistem agroforestry pada kebun belimbing di Desa Manunggal Jaya, Kecamatan Tenggarong Seberang. Penelitian ini dilakukan dalam rangka untuk mendapatkan informasi jenis-jenis tanaman yang diusahakan untuk mengetahui potensi pengembangan sistem agroforestry dalam upaya peningkatan fungsi ekonomi dan ekologi lahan. Diharapkan informasi penelitian ini dapat menjadi rekomendasi dalam upaya perbaikan demi terwujudnya sistem agroforestry yang produktif dan berkelanjutan. Tujuan Penelitian adalah bertujuan untuk mendeskripsikan pola agroforestry dari aspek ekologi dan ekonomi pada kebun belimbing di Desa Manunggal Jaya, Kecamatan Tenggarong Seberang, Kabupaten Kutai Kartanegara.

\section{METODA PENELITIAN}

\subsection{Tempat dan Waktu}

Penelitian ini dilaksanakan di Desa Manunggal Jaya, Kecamatan Tenggarong Seberang Kabupaten Kutai Kartanegara, Kalimantan Timur. Pada bulan Juni-Juli 2019.

\subsection{Bahan dan Alat}

Alat dan bahan yang digunakan dalam penelitian ini adalah : Meteran, untuk mengukur luasan lahan; Kamera digital, untuk dokumentasi di lapangan; Laptop, untuk pengolahan data; Kuisioner, untuk memperoleh informasi; Alat tulis menulis.

\subsection{Metode Penelitian}

Penelitian ini menggunakan metode ekplorasi melalui observasi langsung dilapangan dan wawancara sebagai alat pengumpulan data. Untuk penentuan lokasi penelitian ditetapkan secara sengaja dengan mempertimbangkan kesesuaian lahan dengan tujuan penelitian. Jenis data yang dikumpulkan meliputi data primer dan data sekunder, yaitu :

1. Data primer

Data primer adalah data yang diperoleh dengan menggunakan teknik wawancara terstruktur melalui kuisioner dan pengamatan secara langsung di lapangan dengan memperhatikan aspek ekologi yang memuat tentang biodiversitas, yaitu pola agroforestry; jenis tanaman yang diusahakan baik tanaman semusim, serta tanaman perkebunan maupun tanaman buah.

2. Data sekunder

Data sekunder adalah data yang diperoleh dari Kantor Kepala Desa Manunggal Jaya, Kecamatan Tenggarong Seberang, dan internet.

\subsection{Prosedur Penelitian}

Prosedur penelitian yang ditempuh selama penelitian meliputi :

1. Studi Pustaka

Pada studi pustaka (literatur) dapat diperoleh informasiinformasi atau data sekunder yang berasal dari sumber pustaka (literatur), misalnya dari Kantor Kepala Desa dan internet.

2. Orientasi lapangan

Orientasi lapangan dimaksudkan untuk mengetahui keadaan umum lokasi penelitian serta objek ataupun titik berat penelitian, guna persiapan penelitian. 
3. Persiapan

Persiapan penelitian mencakup pembuatan proposal penelitian, dan merencanakan proses pengambilan data.

4. Pelaksanaan

Pelaksanaan pengambilan data-data dilapangan yang berkaitan dengan kegiatan perkembangan.

\subsection{Analisa Data}

Tahap analisis data dalam penelitian ini adalah sebagai berikut (Gray, Clive dkk. 2005) :

1. Net Present Value (NPV)

NPV merupakan selisih antara "present value benefit" dan "present value" dari biaya yang dinyatakan dengan rumus :

$$
N P V=\sum_{t-1}^{n} \frac{B t-C t}{(1+1)^{t}}
$$

dimana : $\quad \mathrm{Bt}=$ benefit sosial kotor dari proyek pada tahun ke $\mathrm{t}$

$\mathrm{Ct}=$ biaya kotor dari proyek pada tahun ke $\mathrm{t}$, tidak menganggap apakah biaya itu modal atau biaya rutin

$\mathrm{n}=$ umur ekonomis dari proyek tersebut

$\mathrm{i}=$ social opportunity cost of capital yang ditujukan sebagai social discount rate

Droyek tertentu tanda "go" dinyatakan oleh nilai NPV lebih besar dengan nol dan jika NPV sama dengan nol berarti proyek tersebut memberikan persis sebesar social opportunity cost of capital, sedang bila NPV lebih kecil dari nol berarti proyek ditolak artinya penggunaan lain yang lebih menguntungkan untuk sumber-sumber yang diperlukan proyek.
2. Net Benefit Cost Ratio (Net B/ C Ratio)

Merupakan perbandingan sedemikian rupa sehingga pengambilan terdiri dari present value total daripada benefit bersih pada tahun-tahun dimana benefit bersih bersifat positif seddang penyebutnya terdiri dari present value daripada benefit bersih dalam tahun-tahun dimana benefit bersih bersifat negative dengan rumus sebagai berikut:

$$
\text { Net B/C Ratio }=\sum \frac{\left.\frac{(B-C)^{t}}{(1+1)^{t}}(\text { positif })\right)}{\frac{(P-C)^{t}}{(1+1)^{t}}(\text { negatif) }}
$$

Apabila nilai $\mathrm{B} / \mathrm{C}>1$, program/ proyek layak untuk dilaksanakan dan bila nilai $\mathrm{B} / \mathrm{C}<1$, program/ proyek tidak layak untuk dilaksanakan.

3. Internal Rate of Return (IRR)

Nilai IRR adalah nilai discount rate (i) sehingga NPV program/ proyek sama dengan 0

(nol). NPV dapat dinyatakan

dengan persamaan: 


$$
\mathrm{IRR}=\mathrm{i}+\frac{\mathrm{NPV}}{\mathrm{NPV}^{I}-\mathrm{NPV}^{\mathrm{II}}}\left(\mathrm{i}^{\prime \prime}-\mathrm{i}^{\prime}\right)
$$

Rumus ini berlaku asal salah satu dari nilai $\mathrm{Bt}-\mathrm{Ct}$ bersifat negatif selama umur proyek dan bila nilai $\mathrm{Bt}-\mathrm{Ct}$ selalu positif yaitu tidak pernah terjadi investasi dalam arti yang sebenarnya maka nilai IRR tidak terhingga. Suatu proyek dapat dikatakan "go" apabila nilai IRR lebih besar atau sama dengan social discount rate yang berlaku.

Bila nilai IRR > sosial discount rate, maka program/proyek layak dilaksanakan dan bila nilai IRR $<$ sosial discount rate, maka program/ kegiatan tidak layak dilaksanakan.

\section{HASIL PENELITIAN DAN PEMBAHASAN}

\subsection{Letak Geografis dan Luas}

Desa Manunggal Jaya dibentuk pada tahun 1982 dengan dasar hukum transmigrasi dan terletak di Kecamatan Tenggarong Seberang, Kabupaten/Kota Kutai Kartanegara, Provinsi Kalimantan Timur. Secara geografis Desa Manunggal Jaya terletak pada Koordinat Bujur 117,186302 dan Koordinat Lintang 0,269468. Secara geografis Desa Manunggal Jaya mempunyai batas-batas wilayah sebagai berikut:
A. Sebelah Utara
Desa
Bangun Rejo.
B. Sebelah Selatan Karang Tunggal.
Desa
C. Sebelah Timur
: Kelurahan
Sempaja Utara.
D. Sebelah Barat
Tanjung Batu.
Jarak dari Desa Manunggal Jaya
ke Pusat Pemerintahan:

E. Jarak dari Pusat Kota

F. Jarak dari ibu kota Kabupaten : $15 \mathrm{Km}$

G. Jarak dari ibu kota Provinsi : $15 \mathrm{Km}$

Berdasarkan data dari Monografi Desa Tahun 2018 bahwa luas wilayah Desa Manunggal adalah sebesar 17,1 $\mathrm{Km}^{2}$ dengan tipologi desa persawahan dan perladangan.

\subsection{Pembagian Luas Wilayah Desa Manunggal Jaya}

Berdasarkan data dari Profil Desa Manunggal Jaya Tahun 2018, pembagian luas wilayah Desa Manunggal Jaya menurut penggunaan tanah sawah tadah hutan seluas $286 \mathrm{Ha}$, tanah kering tegal/ladang seluas $650 \mathrm{Ha}$ Pemukiman 199 Ha dan pekarangan $103 \mathrm{Ha}$, tanah rawa seluas $3 \mathrm{Ha}$, tanah perkebunan perorangan seluas $39 \mathrm{Ha}$, tanah fasilitas umum seperti lapangan olahraga seluas 1,5 $\mathrm{Ha}$ perkantoran pemerintah $4 \mathrm{Ha}$ tempat pemakaman desa/umum seluas 2 Ha bangunan sekolah/ perguruan tinggi 4,5 Ha pertokoan $2 \mathrm{Ha}$ fasilitas pasar 1 Ha jalan $15 \mathrm{Ha}$, tanah hutan asli seluas $400 \mathrm{Ha}$. Sementara iklim yang berada di Desa Manunggal Jaya untuk jumlah bulan hujan selama \pm 6 bulan kelembaban $32^{\circ}$ suhu rata-rata harian yaitu $20^{\circ} \mathrm{C}$. Untuk warna tanah (sebagian besar) berwarna merah/kuning/hitam/abu-abu tekstur lempungan/berpasir/berbedu daln lahan terlantar seluas $\pm 20 \mathrm{Ha}$.

\subsection{Jumlah Penduduk Desa Manunggal Jaya \\ Desa Manunggal Jaya memiliki total penduduk sebanyak 6.479 jiwa}


dengan jumlah penduduk laki-laki sebesar 3.318 jiwa dan penduduk perempuan sebesar 3.161 jiwa. Jumlah Kepala Keluarga (KK) yang ada di Desa Manunggal adalah 1.856 Kepala Keluarga (KK).

Berdasarkan data mata pencaharian diatas, seperti jumlah pekerja petani pada Desa Manunggal Jaya yang berjumlahkan 567 orang bisa menjadi aset guna pengembangan lahan yang digarapnya dengan menjadikan usaha kebun belimbing ini sebagai referensi untuk lebih mengembangkan lahan garapannya untuk lebih baik lagi. Dengan pengalaman pemanfaatan lahan yang telah dimiliki dari masing-masing petani dengan memadukan tanaman pertanian dan kehutanan seperti pada kebun belimbing ini harapannya lebih menambah pemasukan atau menjadi sumber ekonomi dalam jangka pendek dan jangka panjang bagi petani itu sendiri, sehingga kemakmuran masyarakat desa manunggal jaya bisa lebih baik lagi dan lebih berkembang.

Berdasarkan data diatas, dimulai dari tingkatan TK, SD, sampai dengan SMP bisa menjadikan kebun belimbing ini sebagai sumber pengetahuan atau tempat untuk edukasi. Dimana komponen yang terdapat pada kebun belimbing ini bukan hanya berbicara tentang pemanfaatan lahan, tetapi anak-anak dari tingkatan TK sampai dengan SMP bisa lebih mengetahui satwa yang terdapat pada kebun belimbing ini sekaligus bisa merasakan sarana hiburan lain seperti kolam renang dan lain-lain sebagai tempat bermain anak-anak, dengan demikian secara tidak langsung jumlah pengunjung di kebun belimbing bisa bertambah dan tentunya menjadi sumber pemasukan pula bagi pemilik lahan/petani. Sedangkan pada tingkatan SMU sampai dengan Pasca Sarjana bisa dijadikan sarana untuk memberikan saran ataupun masukan-masukan pada pemilik lahan dalam pengembangan usaha agar usaha kebun belimbing ini dapat lebih baik lagi kedepannya.

Berdasarkan data diatas, seperti jumlah orang yang telah mengikuti kursus pendidikan bisa diundang/diajak guna mengajarkan dan menambah pengetahuan tentang keterampilan kepada pemilik lahan/petani, sehingga kedepannya pemilik lahan/ petani lebih bisa mengembangkan usaha kebun belimbing ini dengan keterampilan yang dimilikinya.

Tabel 1. Potensi Sumber Daya Manusia Berdasarkan Umur

\begin{tabular}{ccc}
\hline Usia & Laki-laki (Orang) & Perempuan (Orang) \\
\hline $0-12$ bulan & 58 & 52 \\
$1-3$ tahun & 148 & 131 \\
$4-6$ & 199 & 150 \\
$7-9$ & 201 & 156 \\
$10-13$ & 220 & 263 \\
$14-16$ & 142 & 167 \\
$17-19$ & 158 & 158 \\
$20-22$ & 144 & 184 \\
$23-25$ & 181 & 154 \\
$26-28$ & 146 & 160 \\
$29-31$ & 144 & 153 \\
$32-64$ & 1299 & 1296 \\
$65-75$ & 93 & 108 \\
75 keatas & 33 & 37 \\
\hline
\end{tabular}


Berdasarkan data umur diatas, dapat disimpulkan bahwasannya usia tidak produktif dimulai pada umur 0-16 tahun masih lebih sedikit dibandingkan masa produktif dari umur 17-64 tahun. Dengan demikian, berdasarkan sumber daya manusia yang ada pada Desa manunggal Jaya dapat dikatakan produktif apabila SDM yang ada dapat diberdayakan dengan baik oleh pemerintah setempat. Sehingga daerah setempat bisa lebih baik dan berkembang.

\subsection{Gambaran Umum Lokasi Penelitian}

Usahatani kebun belimbing di Desa manunggal Jaya Kecamatan Tenggarong Seberang Kabupaten Kutai Kartanegara Provinsi Kalimantan Timur dimulai pada tahun 1989, merupakan kegiatan usaha perorangan/individu dari petani berupa pemanfaatan lahan dengan pola agroforestry yang dimulai dengan penanaman sayur-sayuran atau tanaman pertanian. Pada tahun 2015 timbul pemikiran dengan percobaan penanaman tanaman kehutanan yang diharapkan dapat memberikan keuntungan dari segi finansial sekaligus bernilai ekowisata bagi para pengunjung. Usaha kebun belimbing sudah memasuki tahun ke- 4 . Dalam pembentukan usaha kebun belimbing sebelumnya, petani melakukan tahapan-tahapan sebagai berikut :

Pra tanam

Sebelum lahan dikerjakan diadakan batas lahan sesuai luasan yang hendak digarap, kemudian pemasangan patok batas lahan yang dimiliki, dilanjutkan land clearing/ pembersihan lahan, yakni : mulai dengan merintis tumbuhan yang rumput-rumput dan belukar, baik yang dilakukan dengan penyemprotan gulma-gulma dengan menggunakan herbisida maupun dengan penebasan menggunakan parang dan arit, penebangan tanaman-tanaman besar dilanjutkan dengan pembakaran dan pembersihan sisa-sisa kayu, ranting dan rumput-rumput. Adapun biaya yang diperlukan dalam kegiatan ini sekitar \pm 15.000 .000 .

Tanam

Sebelum dilakukan penanaman, maka terlebih dahulu dilakukan pembersihan sisa-sisa rumput/gulma dengan penyemprotan menggunakan herbisida. Kemudian dilakukan pembuatan lubang untuk pohon belimbing dengan jarak tanam yang ditentukan secara perkiraan sekitar \pm $7 \mathrm{~m} \times 7 \mathrm{~m}$, dengan kebutuhan bibit 180 pohon, dilanjutkan dengan penanaman tanaman kehutanan lainnya seperti jambu air, jambu kristal, rambutan, petai, nangkadak, dan durian, serta pengembangan usaha peternakan yang mempunyai nilai finansial dan ekowisata sebagai pendukung usaha petani/ pemilik. Adapun biaya yang diperlukan dalam kegiatan ini sekitar \pm 200.000.000.

Pemeliharaan

Pemeliharaan yang dilakukan meliputi : pemupukan, pemangkasan, penyiangan, dan pendangiran yang dimana dilakukan dengan menyesuaikan atau keperluan tanaman yang telah ditanam, serta pengendalian hama/ penyakit penyemprotan menggunakan pestisida/ obat-obatan lainnya. Adapun biaya yang diperlukan dalam kegiatan ini sekitar \pm 30.000 .000 .

Panen 
Petani mulai melakukan pemanenan belimbing pada tahun tahun 2017 setelah belimbing berumur 1,5 tahun, atau sudah mencapai $50 \%$ tanaman yang sudah mencapai ketinggian $\pm 1,5 \mathrm{~m}$ dari permukaan tanah. Untuk jenis tanaman jambu air dan jambu kristal mulai panen pada tahun 2017, dimana untuk jenis tanaman belimbing, jambu air dan jambu kristal merupakan jenis tanaman andalan dari petani dimana untuk jenis tanaman ini merupakan pendapatan finansial yang bisa didapatkan dalam setiap harinya yang dibeli oleh supermarket, mall, dan pengumpul/pedagang lainnya. Disamping itu juga ada kolam renang yang menjadi pemasok bulanan sebagai usaha pendukung. Adapun pendapatan dari usaha kebun belimbing ini sekitar \pm 50.000.000 pertahunnya dimulai dari tahun berjalan pada tahun 2010 dan berdasarkan hasil pendapatan/panen dari usaha kebun belimbing ini tiap tahunnya kian meningkat, dikarenakan setiap tahunnya jumlah produksi dari masing-masing jenis semakin bertambah. Sebagai contoh pada tanaman belimbing yang mulai panen pertama sekitar $10-15 \mathrm{~kg}$ hingga kini panen telah mencapai 50 $\mathrm{kg}$ perharinya.

\subsection{Analisis Aspek Ekologi}

Upaya pemanfaatan lahan untuk meningkatkan kesejahteraan dilakukan oleh petani/pemilik lahan dengan menerapkan beberapa pola yang sudah ada di Indonesia, dimulai dari penanaman tanaman palawija yang dianggap pada saat itu dapat memberikan keuntungan langsung kepada pemilik lahan. Seiring berjalannya waktu timbul pemikiran untuk menciptakan suatu terobosan baru dengan menanam tanaman kehutanan (buah). Setelah penanaman tanaman kehutanan (buah) dianggap masih perlu pengembangan usaha guna mendapatkan hasil/keuntungan dari jumlah luasan yang ada. Dengan demikian juga secara tidak sengaja pola-pola agroforestry yang sudah berkembang di Indonesia pun tercipta didalamnya. Menurut Nair (1989), klasifikasi agroforestry dapat juga ditinjau dari penyebarannya atau didasarkan pada zona Agroekologi. Agroforestry adalah bentuk pemanfaatan lahan secara optimal dalam suatu tapak yang mengusahakan produksi biologi berdaur pendek atau berdaur panjang (kombinasi kegiatan kehutanan bersamasama dengan kegiatan pertanian lainnya) berdasarkan kelestarian, baik secara serempak maupun secara berurutan di dalam atau di luar kawasan hutan untuk kesejahteraan masyarakat (Indriyanto, 2006). Menurut De Foresta dan Michon (1997), agroforestry dapat dikelompokkan menjadi dua sistem, yaitu agroforestry sederhana dan sistem agroforestry kompleks. Bentuk agroforestry sederhana yang paling banyak dibahas di Jawa adalah tumpangsari (Bratamihardja, 1991 dalam Soemitro, 2001; Lahjie, 1990). Bentuk, fungsi, dan perkembangan agroforestry dipengaruhi oleh berbagai faktor biologis dan sosial (FAO dan IRR, 1995).

Berdasarkan pengamatan dilapangan, tajuk yang rapat dimiliki oleh masing-masing tanaman tentunya mempunyai dampak yang positif yaitu dapat mengintersepsi dan menyimpan sejumlah air hujan dalam bentuk lapisan tipis air pada permukaan daun dan batang yang selanjutnya akan mengalami evaporasi sebelum jatuh ke tanah. Apabila curah hujan tinggi, peran intersepsi pohon penting dalam kaitannya dengan pengurangan banjir. Hal ini dapat dilihat dilapangan bahwasannya lahan yang berada dataran yang lebih tinggi tetap terjaga dan kuat sehingga tidak 
terjadinya penurunan terhadap kualitas tanah.

Kemudian vegetasi dan lapisan serasah dapat melindungi permukaan tanah dari pukulan langsung tetesan air hujan yang dapat menghancurkan agregat tanah, sehingga terjadi pemadatan tanah. Serasah yang kemudian terdekomposisi dengan sendirinya akan menjadi ketersediaan makanan bagi biota tanah (terutama cacing tanah). Selanjutnya hasil daripada kotoran hewan ternak yang ada pada kebun belimbing dapat dimanfaatkan sebagai pupuk bagi tanaman-tanaman yang ada, sehingga untuk pengeluaran pembelian pupuk dapat terminalisir.

Adapun pola dari masing-masing jenis tanaman akan diuraikan sebagai berikut

a. Pohon Belimbing

Belimbing/belimbing manis adalah tumbuhan penghasil buah berbentuk khas yang berasal dari Indonesia, India, Sri Langka,. Saat ini, belimbing telah tersebar ke penjuru Asia Tenggara, Republik Dominika, Brasil, Peru, Ghana, Guyana, Tonga, dan Polinesia. Belimbing (Averrhoa carambola) termasuk dalam kingdom Plantae, Famili Oxalidaceae, dan Ordo Oxalidales . Buah belimbing manis (Averrhoa carambola L.) merupakan salah satu buah nonklimaterik berkulit tipis dengan kadar vitamin C yang tinggi (Sukadana, 2009). Untuk pola tanam belimbing ini sendiri termasuk dalam pola tanam teratur dengan jarak tanam $7 \mathrm{~m} \times 7 \mathrm{~m}$ dan jumlah dari pohon belimbing yang ditanam sebanyak 180 pohon, dan sampai pada saat ini usia pohon belimbing ini telah mencapai 4 tahun dari tahun tanam 2015 lalu.

Pohon belimbing yang terdapat pada lokasi penelitian merupakan tanaman yang paling banyak memberikan kontribusi dari segi finansial, dimana pendapatan perharinya diperkirakan mencapai $50 \mathrm{~kg}$ dengan asumsi 1 pohon dapat menghasilkan 10 biji buah dengan harga penjualan \pm 15.000 perkilonya, yang dimana langsung di distribusikan kepada Supermarket, Mall, para pedagang belimbing, dan para pengunjung kebun belimbing. Dengan demikian pendapatan dari pohon belimbing setiap harinya sekitar $\pm \mathrm{Rp}$. 750.000. Adapun pola dari pohon belimbing ini dapat dilihat pada gambar dibawah ini.

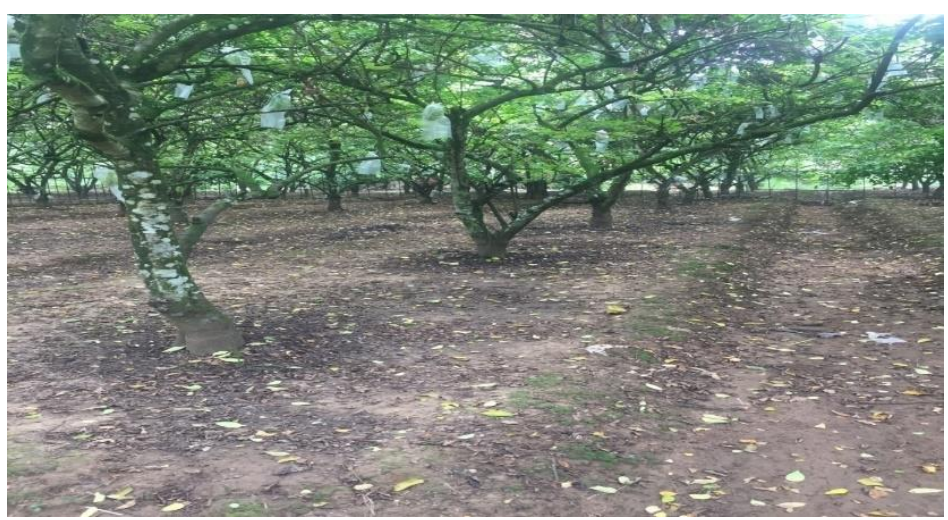

Gambar 1. Tanaman pohon belimbing dengan pola tanam teratur dengan jarak $7 \mathrm{~m} \mathrm{x} 7 \mathrm{~m}$.

\section{b. Pohon Jambu Air}

Jambu air merupakan tanaman tahunan yang memiliki perawakan berupa pohon. Menurut Chi et al. (2014) secara umum jambu air (S. samarangense) memiliki tinggi sekitar 12-15 m, namun 
pohon pada kebun yang dikelola memiliki tinggi berkisar 4-5 m. Hal ini tidak berbeda jauh dengan hasil pengamatan tinggi pohon pada varietas jambu air yang diamati yakni berkisar 4,2-8,1 m. Menurut Margianasari et al. (2013) pohon yang berasal dari perbanyakan vegetatif memiliki tajuk lebih pendek. Pohon jambu air ini sendiri ditanam dengan pola tanam teratur dengan jarak tanam $6 \mathrm{~m} \times 6 \mathrm{~m}$ dan jumlah pohon yang ditanam sebanyak 70 pohon. Pohon jambu air ini sudah memasuki usia 3 tahun, dan pemasukan/produksi buah jambu air ini perharinya mencapai $20 \mathrm{~kg}$.

\section{c. Pohon Jambu Kristal}

Jambu kristal memiliki berbagai kesamaan dengan jenis jambu biji lain yaitu dapat tumbuh di berbagai jenis tanah tetapi lebih subur di daerah tropis dengan ketinggian 5-1200 mdpl, curah hujan 1000-2000 mm/tahun, suhu $25-30^{\circ}$ $\mathrm{C}$, serta $\mathrm{pH}$ 4.5-8.2. Jambu Kristal (Psidium guajava (L) Merr termasuk dalam kingdom Plantae divisi Spermatophyta dan family Myrtaceae, kini sudah memasuki usia 2 tahun dari tahun penanaman pada 2017 lalu dan hingga kini sudah dapat memproduksi \pm $30 \mathrm{~kg}$ perharinya. Pola untuk Jambu Kristal ini sendiri adalah pola tanam teratur dengan jarak tanam $5 \mathrm{~m}$ x $5 \mathrm{~m}$ dari jumlah pohon yang ditanam sebanyak 200 pohon.

\section{d. Pohon Rambutan}

Rambutan banyak ditanam sebagai pohon buah dan kadang-kadang ditemukan tumbuh liar. Tumbuhan tropis ini memerlukan iklim lembab dengan curah hujan tahunan paling sedikit 2000 mm. Rambutan merupakan tanaman dataran rendah yang ketinggiannya mencapai 300-600 mdpl. Pohon dengan tinggi $15-25 \mathrm{~m}$ ini mempunyai banyak cabang. Pohon rambutan (Nephelium lappaceum, L) termasuk dalam kingdom Plantae divisi Magnoliophyta dan family Sapindaceae. Pola untuk pohon rambutan ini adalah pola tanam teratur dengan jarak tanam $10 \mathrm{~m} \times 10 \mathrm{~m}$ dari jumlah yang ditanam sebanyak 35 pohon. Pohon Petai

Petai (Parkia speciosa Hassk.) merupakan tanaman tahunan tropika dari famili Fabaceae, subfamili Mimosoideae. Tanaman ini banyak ditemukan dibeberapa negara di Asia Tenggara, seperti Indonesia, Malaysia, Thailand, dan India Utara. Biji petai kaya akan kandungan mineral, seperti kalsium, fosfor, potasium, magnesium, mangan, dan zat besi (Mohamed et al., 1987). Selain itu, komponen gizi biji petai juga cukup lengkap karena mengandung karbohidrat dan protein yang tinggi, lemak, asam lemak jenuh dan tak jenuh, serta memiliki banyak vitamin $\mathrm{C}$ dan $\alpha$ tokoferol (vitamin E) (Maisuthisakul et al., 2008; Azizi et al., 2008). Kandungan protein dan karbohidrat petai (per $100 \mathrm{~g}$ edible portion) cukup tinggi berkisar 6,0 - 27,5 dan 13,2 - 52,9, masing-masing (Maisuthisakul et al., 2008).

e. Nangkadak

Nangkadak adalah tanaman hasil rekayasa genetika Taman Wisata Mekarsari (TWM). Menurut Margianasari (Tim ahli TWM), asal kultivar Nangkadak Mekarsari merupakan persilangan antara nangka mini sebagai tetua betina dengan cempedak lokal sebagai tetua jantan. Keduanya merupakan koleksi plasma nutfah dari kebun koleksi tanam wisata mekarsari. Nangkadak (Arthocarpus champeden) termasuk didalam Kingdom Plantae divisi Spermatophyta famili Moraceae dan genus Artocarpus. Pola untuk nangkadak ini adalah pola tanam teratur dengan jarak $5 \mathrm{~m} \times 5 \mathrm{~m}$ dan berjumlahkan 250 pohon. Untuk saat ini nangkadak sudah berusia 1 tahun dari 
tahun tanam 2018 dan sampai saat ini nangkadak belum menghasilkan buah.

\section{f. Pohon Durian}

Durian merupakan tanaman buah berupa pohon. Sebutan durian diduga berasal dari istilah melayu yaitu dari kata duri yang diberi akhiran -an sehingga menjadi durian. Kata ini sering dipergunakan untuk menyebut buah yang kulitnya berduri tajam. Tanaman durian (Durio zibethinus Murr) termasuk family Malvaceae sebangsa pohon kapukkapukan (Sihontang, 2010) divisi Magnoliophyta dan genus Durio. Pohon durian ini sendiri telah berumur 7 tahun dan sampai saat ini baru memasuki masa buah. untuk pola pohon durian ini adalah pola tanam acak berjumlahkan 3 pohon.

\section{g. Pepaya}

Pepaya merupakan tanaman yang berasal dari Amerika Tengah. Pepaya dapat tumbuh dengan baik di daerah yang beriklim tropis. Tanaman pepaya oleh para pedagang Spanyol disebarluaskan ke berbagai penjuru dunia. Negara penghasil pepaya antara lain Costa Rica, Republik Dominika, Puerto Riko, dan lain-lain (Warisno, 2003). Pepaya merupakan tanaman dari suku Caricaceae dengan Marga Carica. Marga ini memiliki kurang lebih 40 spesies, tetapi yang dapat dikonsumsi hanya tujuh spesies, diantaranya Carica papaya L. Pepaya yang ada dilokasi penelitian menggunakan pola tanam teratur dengan jarak tanam $4 \mathrm{~m}$ x $4 \mathrm{~m}$ dan berjumlahkan 150 pokok.

\subsection{Analisis Finansial Usaha}

Biaya yang diperlukan yaitu biaya tetap Rp.72.000.000.00,- dan biaya variabel untuk keseluruhan kegiatan pengusahaan kebun belimbing yang disusun berdasarkan aliran kas dengan jangka waktu usaha 10 tahun. Biayabiaya yang dikeluarkan dalam pengusahaan kebun belimbing terdiri dari

1. Biaya usaha
A. Biaya Tetap (modal)
B. Biaya Variabel (rutin)

2. Analisis langkah usaha :
A. Net Present Value (NPV)
B. Internal Rate of Return (IRR)
C. Net B/C Ratio

Berikut penjelasan mengenai analisis finansial usaha dari biaya usaha sampai dengan analisis langkahlangkah usahanya.

\section{A. Biaya Tetap (modal)}

Biaya tetap usahatani kebun belimbing ini terdiri dari biaya-biaya yang dikeluarkan dalam setiap bulannya sebesar Rp. 6.000.000,- untuk kebutuhan hidup petani/ pemilik serta upah tenaga harian (gajih karyawan 1 HOK). disajikan dalam Tabel 2 Berikut :

Tabel 2. Biaya Tetap per tahun yang diperlukan dalam usahatani kebun belimbing di Desa Manunggal Jaya Kecamatan Tenggarong Seberang Kabupaten Kutai Kartanegara.

\begin{tabular}{cccc}
\hline NO & Komponen Biaya & Waktu & Biaya (Rp) \\
\hline 1. & Upah tenaga dalam keluarga (petani) & 1 tahun & $36.000 .000,-$ \\
2. & Upah tenaga diluar keluarga (buruhtani) & 1 tahun & $36.000 .000,-$ \\
\hline \multicolumn{2}{r}{ Jumlah Biaya } & $\mathbf{7 2 , 0 0 0 , 0 0 0 , -}$ \\
\hline
\end{tabular}

Sumber : Data primer (diolah) 
B. Biaya Variabel (rutin)

Biaya Variabel yang dikeluarkan dalam usaha kebun belimbing selama 10 tahun terakhir, sejak tahun 2010 sampai dengan 2020. Dari berbagai komponen biaya variabel dapat dilihat pada Tabel 3 berikut.

Tabel 3. Biaya Variabel dalam hitungan per tahun dari tahun 2016 pada kebutuhan kebun belimbing di Desa Manunggal Jaya Kecamatan Tenggarong Seberang Kabupaten Kutai Kartanegara.

\begin{tabular}{|c|c|c|c|c|}
\hline \multicolumn{2}{|c|}{ B. Biaya Variabel } & \multirow{2}{*}{$\begin{array}{c}\text { Kebutuhan } \\
-\end{array}$} & \multirow[t]{2}{*}{ Biaya } & \multirow[t]{2}{*}{ Ket } \\
\hline 1 & Pengadaan bibit & & & \\
\hline & - Gambas & - & $17,550,000$ & \\
\hline & - Terong & - & $12,950,000$ & \\
\hline & - Pepaya & - & $5,095,000$ & \\
\hline & - Kacang panjang & - & $19,165,000$ & \\
\hline & - Timun & - & $17,425,000$ & \\
\hline & - Lombok & - & $11,931,000$ & \\
\hline & - Belimbing & - & $47,335,000$ & \\
\hline & - Jambu air & - & $49,515,000$ & \\
\hline & - Jambu Kristal & - & $53,175,000$ & \\
\hline & - Nangkadak & - & $22,935,000$ & \\
\hline & - Durian & - & $5,055,000$ & \\
\hline & - Rambutan & - & $21,220,000$ & \\
\hline & - Petai & - & $20,545,000$ & \\
\hline 2 & Pemanenan & - & 50,000 & \\
\hline 3 & Pemeliharaan & - & & \\
\hline 4 & Pupuk Organik & - & 600,000 & \\
\hline 5 & Pupuk Kimia & - & & \\
\hline & a. Pupuk daun & 84 bungkus & $3,780,000$ & \\
\hline & b. NPK & 3 karung & $1,650,000$ & \\
\hline & c. Pupuk buah & 132 bungkus & $6,600,000$ & \\
\hline & d. Urea & 4 karung & 860,000 & \\
\hline & Pestisida dan Obat lain & - & 850,000 & \\
\hline 6 & Biaya tidak terduga & - & 450,000 & \\
\hline 7 & Biaya transportasi & - & $1,000,000$ & \\
\hline 8 & $\mathrm{BBM}$ & - & $2,000,000$ & \\
\hline 9 & Plastik Kiloan & 360 keping & $4,320,000$ & \\
\hline 10 & Isi Staples & 120 kotak & 300,000 & \\
\hline 11 & Pakan Ikan (sentrat) & - & $4,320,000$ & \\
\hline 12 & Pakan Hewan peliharaan & - & $5,400,000$ & \\
\hline
\end{tabular}

Sumber : Data primer (diolah)

C. Net Present Value (NPV)

Hasil perhitungan Net Present Value (NPV) pada tingkat

suku bunga $8 \%, 10 \%, 12 \%, 14 \%$, $18 \%$ dan $20 \%$ dapat dilihat dari Tabel 4. 
Tabel 4. Nilai Net Present Value (NPV) Usahatani Kebun Belimbing di Kecamatan Tenggarong Seberang Kabupaten Kutai Kartanegara Propinsi Kalimantan Timur.

\begin{tabular}{|l|c|c|c|c|c|c|}
\hline \multirow{2}{*}{$\begin{array}{c}\text { Tahun } \\
\text { Pengusahaan }\end{array}$} & \multicolumn{7}{|c|}{ Discount Rate } \\
\cline { 2 - 7 } & $\mathbf{8 \%}$ & $\mathbf{1 0 \%}$ & $\mathbf{1 2 \%}$ & $\mathbf{1 4 \%}$ & $\mathbf{1 8 \%}$ & $\mathbf{2 0 \%}$ \\
\hline $0-5$ & -88.078 .150 & -23.730 .000 & -105.669 .779 & -112.596 .356 & -123.509 .855 & -127.750 .695 \\
\hline $6-10$ & 1.747 .418 .654 & 3.669 .990 .000 & 1.216 .947 .496 & 1.015 .777 .166 & 705.579 .598 & 586.153 .801 \\
\hline Nilai Kriteria & \multicolumn{7}{|c|}{ NVP $>\mathbf{0}$} \\
\hline
\end{tabular}

Sumber : Data Primer (diolah)

D. Internal Rate of Return (IRR)

Hasil perhitungan nilai IRR pada masing-masing tingkat suku bunga usahatani kebun belimbing selama 10 tahun terakhir menunjukan nilai Internal of Return akan melebihi nilai tingkat suku bunga yang berlaku mulai pada pengusahaan tahun ke 5 dilihat dalam Tabel 6 .

Tabel 5. Nilai Internal Rate of Return Usahatani Kebun Belimbing di Desa Manunggal Jaya Kecamatan Tenggarong Seberang Kabupaten Tenggarong Seberang Propinsi Kalimantan Timur.

\begin{tabular}{cc}
\hline Tahun Pengusahaan & IRR \\
7 & $19,4 \%$ \\
\hline
\end{tabular}

Sumber : Data Primer (diolah)

E. Net B/C Ratio

Untuk menghitung Net B/C Ratio dilakukan dengan cara membagi nilai positif present value dengan nilai negative present value net benefit pada masing-masing tingkat suku bunga (discount rate). Hasil perhitungan Net B/C Ratio kebun belimbing seluas \pm 2 ha dengan jangka waktu pengusahaan 10 tahun.

Tabel 6. Nilai Net B/C Ratio usahatani kebun belimbing di Desa Manunggal Jaya Kecamatan Tenggarong Seberang Kabupaten Kutai Kartanegara Propinsi Kalimantan Timur.

\begin{tabular}{ccccccc}
\hline Tahun & \multicolumn{7}{c}{ Discount Rate } \\
Pengusahaan & $\mathbf{8 \%}$ & $\mathbf{1 0 \%}$ & $\mathbf{1 2 \%}$ & $\mathbf{1 4 \%}$ & $\mathbf{1 8 \%}$ & $\mathbf{2 0 \%}$ \\
\hline $0-5$ & 0.00 & 0.00 & 0.00 & 0.00 & 0.00 & 0.00 \\
$6-10$ & 2.62 & 5.35 & 1.82 & 1.51 & 1.05 & 0.86 \\
\hline Nilai & & \multicolumn{7}{c}{ Net B/C Ratio $>\mathbf{1}$} \\
Kriteria & & \multicolumn{7}{c}{} \\
\hline
\end{tabular}


F. Rekapitulasi Perhitungan

Kelayakan

Hasil perhitungan analisis

ekonomi usahatani Kebun

Belimbing di Desa Manunggal

Jaya Kecamatan Tenggarong

Seberang Kabupaten Kutai

Kartanegara Propinsi Kalimantan

Timur selama 10 tahun terakhir dapat disimpulkan dari rekapitulasi perhitungan, dapat dilihat pada Tabel 7 berikut. Untuk menilai dan mengukur suatu usaha yang sedang dijalankan layak atau tidak dilakukan maka ada beberapa kriteria yang perlu diperhatikan (Gray, 1992).

Tabel 7. Rekapitulasi Perhitungan Kelayakan Usahatani Kebun Belimbing di Desa Manunggal Jaya Kecamatan Tenggarong Seberang Kabupaten Kertanegara Propinsi Kalimantan Timur selama 10 tahun terakhir.

\begin{tabular}{|c|c|c|c|c|c|c|c|c|}
\hline \multirow[t]{2}{*}{ No. } & \multirow{2}{*}{$\begin{array}{l}\text { Alat } \\
\text { Ukur }\end{array}$} & \multicolumn{6}{|c|}{$\begin{array}{l}\text { Hasil Perhitungan } \\
\text { Discount Rate }\end{array}$} & \multirow{2}{*}{$\begin{array}{c}\text { Keteranga } \\
\mathrm{n}\end{array}$} \\
\hline & & $8 \%$ & $10 \%$ & $12 \%$ & $14 \%$ & $18 \%$ & $20 \%$ & \\
\hline 1 & $\begin{array}{l}\text { Net } \\
\text { Present } \\
\text { Value }\end{array}$ & $\begin{array}{l}1.747 .418 .6 \\
54\end{array}$ & $\begin{array}{l}3.669 .990 .0 \\
00\end{array}$ & $\begin{array}{l}1.216 .947 .49 \\
6\end{array}$ & $\begin{array}{l}1.015 .777 .1 \\
66\end{array}$ & $\begin{array}{l}705.579 .59 \\
8\end{array}$ & $\begin{array}{l}586.153 \\
81\end{array}$ & Baik \\
\hline 2 & $\begin{array}{l}\text { Net } \\
\text { Benefit } \\
\text { Cost } \\
\text { Ratio }\end{array}$ & $\begin{array}{l}551.047 .74 \\
6\end{array}$ & $\begin{array}{l}1.101 .546 .9 \\
95\end{array}$ & 397.228 .889 & $\begin{array}{l}338.734 .45 \\
0\end{array}$ & $\begin{array}{l}248.350 .45 \\
7\end{array}$ & $\begin{array}{l}213.487 \\
.187\end{array}$ & Baik \\
\hline 3 & $I R R$ & & & $19,4 \%(\mathrm{ta}$ & ke 7) & & & Baik \\
\hline
\end{tabular}

Dari Tabel 7 diatas, menunjukan analisis indikator pengukuran Net Present Value (NPV), IRR, dan Net B/C dalam usahatani kebun belimbing layak/ fleisebel diusahakan pada suku bunga $8 \%, 10 \%, 12 \%, 14 \%, 18 \%$, dan $20 \%$ pada jangka waktu 10 tahun terakhir adalah baik (fleasible).

\section{KESIMPULAN}

Berdasarkan hasil penelitian dan perhitungan usahatani kebun belimbing dapat disimpulkan sebagai berikut : Berdasarkan hasil analisis ekologi yang berada di kebun belimbing pada Desa Manunggal Jaya Kecamatan Tenggarong Seberang Kabupaten Kutai Kartanegara adalah sistem agroforestry kebun campuran dengan pola tanam acak dan pola tanam teratur. untuk jenis tanaman belimbing, jambu air, jambu kristal, rambutan, nangkadak, dan pepaya termasuk dalam jenis tanaman dengan pola tanam teratur. Sedangkan untuk jenis tanaman pohon durian dan petai termasuk dalam jenis tanaman dengan pola tanam acak.

Dari hasil analisis ekonomi usahatani kebun belimbing pada Desa Manunggal Jaya Kecamatan Tenggarong Seberang Kabupaten Kutai Kartanegara Propinsi Kalimantan Timur yang dijalankan secara umum dapat dikatakan layak/ feasible diusahakan dalam pengembangannya sebagai alternatif dalam mata pencaharian pokok petani atau pemilik lahan, adapun hasil analisis ekonominya sebagai berikut : Nilai Net Present Value (NPV) dapat dilihat bahwa usahatani kebun belimbing pada tingkat suku bunga $8 \%, 12 \%, 14 \%, 18 \%$, dan $20 \%$ layak diusahakan pada mulai tahun ke-7. Perhitungan IRR menunjukan bahwa usahatani kebun belimbing layak diusahakan dalam jangka waktu pengusahaan tahun ke 7 keatas pada tingkat discount rate maksimal. Nilai Net Benefit Cost Ratio dapat dilihat bahwa usahatani kebun belimbing pada tingkat suku bunga $8 \%, 12 \%, 14 \%, 18 \%$, dan 
$20 \%$ secara ekonomi layak diusahakan pada mulai tahun ke-7.

\section{DAFTAR PUSTAKA}

De Foresta H. and G. Michon. (1997). The Agroforestri alternative to imperata grasslands: when smallholder agriculture and forestry reach sustainability. Agroforestry Systems: 36 : $105-$ 120.

FAO, IRR., (1995). Resource management for unpland areas in SE-Asia. An Information Kit. Farm field document 2. Food and Agriculture Organisation of the United Nations.

Gray, C. (1992). Comparing Public Policies: The Case of Cultural Policy in Western Europe. Leicester Business School, Leicester Polytechnic.

Gray, Clive dkk. (2005). Pengantar Evaluasi Proyek, Edisi Kedua. Jakarta: PT. Gramedia Pustaka Utama.

Hairiah, K. Mustafa, dan Sambas (2003). Pengantar Agroforestry. Bahan Ajaran Agroforestry 1. ICRAF, Bogor.
Indriyanto. (2006). Ekologi Hutan. Jakarta: Bumi Aksara.

Lahjie, A. M. (1990). Agroforestry Suatu Pengantar. Diktat Kuliah Facultas Kehutanan Universitas Mulawarman. Samarinda.

Mahendra, F. (2009). Sistem Agroforestry dan Aplikasinya. Yogyakarta: Graha Ilmu.

Nair PKR. (1989). Agroforestry systems in the tropics. Kluwer Academic Publisher.

Paembonan, S. A. (2012). Hutan tanaman dan serapan karbon. Makassar: Masagena Press.

Soemitro, P. W. (2001). Peranan Hijauan - Legume dan Ternak dalam Pertanian Berkelanjutan. Pidato Pengukuhan Sebagai Guru Besar Fakultas Peternakan UGM.

Utami S. R, Bruno Verbist, Meine Van Noordwijk, Kurniatun Hairiah dan Mustofa Agung Sardjono (2003). Prospek Penelitian dan Pengembangan Agroforestry di Indonesia. World Agroforestry Centre ICRAF. Bogor.

Warisno. (2003). Budidaya Pepaya. Yogyakarta: Kansius. 